\title{
The Principle of Generic Consistency as the Supreme Principle of Human Rights
}

\author{
Deryck Beyleveld
}

Published online: 29 November 2011

(C) The Author(s) 2011. This article is published with open access at Springerlink.com

\begin{abstract}
Alan Gewirth's claim that agents contradict that they are agents if they do not accept that the principle of generic consistency (PGC) is the supreme principle of practical rationality has been greeted with widespread scepticism. The aim of this article is not to defend this claim but to show that if the first and least controversial of the three stages of Gewirth's argument for the PGC is sound, then agents must interpret and give effect to human rights in ways consistent with the PGC, or deny that human beings are equal in dignity and rights (which idea defines human rights) or that they are agents (and hence subject to any rules at all). Implications for the interpretation of the international legal system of human rights inspired by the Universal Declaration of Human Rights 1948 are sketched.
\end{abstract}

Keywords Human rights · Gewirth · Kant · Principle of generic consistency

D. Beyleveld

Durham Law School, University of Durham, Durham, UK

D. Beyleveld

Ethics Institute, University of Utrecht, Utrecht, Netherlands

D. Beyleveld ( $($ )

Durham Law School, University of Durham, 29/30 Old Elvet, Durham DH1 3HN, UK

e-mail: deryck.beyleveld@durham.ac.uk 


\section{Introduction}

According to Alan Gewirth (1978), the principle of generic consistency (PGC) ${ }^{1}$ is the supreme rational reference point for judging the permissibility of all actions. This is because the PGC is 'dialectically necessary' for agents (which is to say that agents contradict that they are agents if they consider that they may act in ways inconsistent with the PGC), and it cannot be rational for an agent to act in ways that the agent cannot coherently conceive of doing.

Human rights ${ }^{2}$ impose duties on individual agents or groups of agents ${ }^{3}$ to act out of respect for these rights. If the PGC governs all permissible action, it also governs the existence of human rights by governing the correlative duties as well as any actions that are involved in exercising a human right.

The dialectically necessary argument has three stages (Beyleveld 1991, pp. 1346). Stage I contends that any agent (e.g., Albert) contradicts that he is an agent if he does not accept that he generically instrumentally (i.e., in order to pursue or achieve his own purposes, regardless of what these might be) ought to defend his possession

\footnotetext{
${ }^{1}$ The PGC prescribes that agents categorically ought to act out of respect for the generic rights of all agents. Action involves doing things voluntarily in order to achieve one's freely chosen purposes. The generic rights are rights to generic conditions (or needs, or interests) of agency. Generic conditions of agency are needed for action or successful action in that deprivation of, or interference with, such a condition has some negative effect (or will have such an effect, if prolonged) on an agent's ability to pursue or achieve the agent's purposes regardless of what these are. Generic conditions of agency divide into basic needs (needed to be able to act at all; ibid. pp.53-54); non-subtractive needs (needed to maintain an agent's ability to act; ibid. pp.54-55); and additive needs (needed in order to be able to improve an agent's ability to act; ibid 56). Non-subtractive and additive needs are needed for successful action rather than action per se (ibid. pp.58-63). Generic conditions of agency also divide into substantive needs ('well being') and procedural needs ('freedom'; ibid. pp.41, 54). Basic well being includes life itself and mental equilibrium sufficient to permit the agent to pursue ends the agent wants to pursue, and the necessary means to these, such as (for human agents) food, shelter, bodily and mental integrity and health (ibid. p.54). Basic freedom includes the freedom to act according to one's chosen purposes and freedom of thought (ibid. pp.52-53). Non-subtractive needs include provision of accurate information and being able to rely on promises. Additive needs include access to new information and opportunities to learn new skills. The identification of generic conditions requires careful analysis, and these examples are illustrative only. The validity of Gewirth's argument for the PGC does not depend on this as it is couched in terms of the abstract idea of generic conditions of agency, their instantiation being left to applications of the PGC.

2 The rights of the international legal system of human rights are axiomatically rights held simply by virtue of being human. As such, they are necessarily inalienable; they cannot be denied to any human, and all humans are equal in dignity (their entitlement to human rights) and must be treated with equal concern and respect for their human rights. It matters whether human rights are viewed as belonging to humans individually or as parts of a system of rights. If they belong individually, all humans must have exactly the same specific human rights, to the same degree and with equal force. If they belong only as parts of a system, this is not necessarily the case. Given the human rights recognised by the international system, the latter is the only defensible view (see further below).

${ }^{3}$ The international system consists of instruments agreed between nation states, which require members to give effect in their domestic law to the recognised rights. It follows that individuals cannot bring domestic legal actions directly against private individuals under these instruments unless domestic law allows, and they cannot bring actions against private individuals at all in applicable international courts - they can only bring them against the state. However, this does not mean that human rights are held only against the state (i.e., only impose duties on state actors). They impose duties on all agents, which under the instruments of the international system are only enforceable (effective) directly against state actors (who have duties under these instruments to pass domestic laws to enable individuals to enforce these duties against individuals as well as state actors; Beyleveld and Pattinson 2002).
} 
of the generic conditions of agency. Stage II argues that it follows purely logically that it is dialectically necessary for Albert to consider that he has rights to the generic conditions of agency (i.e., that, subject to Albert's will, other agents categorically ought to act out of respect for Albert's need for these conditions). Finally, stage III contends that it follows purely logically that it is dialectically necessary for Albert to consider that all agents have these 'generic rights' equally. Since Albert represents any agent, it is dialectically necessary for all agents to accept that all agents have the generic rights.

In "Part One: The Dialectically Necessary Argument", I outline this argument, but my aim here is not to defend it in its entirety, but to show, in "Part Two: An Alternative Argument", that if Stage I is sound it is dialectically necessary for human rights to be interpreted and effected in ways consistent with the PGC, on pain of denying that all human beings are equal in dignity and rights: (i.e., the interpreter or implementer of a human rights instrument can only defend not applying the PGC by contradicting that he or she is an agent or by denying that human beings are equal in dignity and rights).

In "Part Three: Interpretive Effect and Limitations of the Alternative Argument", I sketch the implications for the interpretation of the international legal system of human rights, which is inspired by the Universal Declaration of Human Rights 1948 (UDHR), and explain the limitations of the argument presented in "Part Two: An Alternative Argument".

\section{Part One: The Dialectically Necessary Argument}

Like Kant's argument for 'the moral law' (1785, 4:445), this aims to demonstrate that the idea of morality, viewed as a categorically binding set of norms requiring all agents to be treated with equal concern and respect, is not a delusion. Kant cogently maintains that if morality is characterised as categorically binding such a demonstration must establish that the moral law is 'connected (completely a priori) with the concept of the will of a rational being as such' (ibid. 4:426). Similarly inspired, Gewirth's dialectically necessary argument tries to show that agents contradict that they are agents unless they accept that the permissibility of all their actions is to be judged by the PGC. ${ }^{5}$

\section{Stage I}

The argument is conducted from the internal viewpoint of a representative agent (Albert). All its steps must follow purely logically from the mere idea that Albert is an agent from within Albert's perspective as an agent. When Albert contemplates the

\footnotetext{
${ }^{4}$ A wide-ranging collection of sceptical responses is to be found in Regis (1984), which includes a detailed response by Gewirth. For a detailed defence, see Beyleveld (1991). For some other defences, see Steigleider (1992) and Spence (2006). Important essays are also to be found in Boylan (1999).

${ }^{5}$ Kant's concept of a rational being with a will is equivalent to Gewirth's concept of an agent. For discussion of how Kant's and Gewirth's arguments for a categorical imperative relate to each other, see Beyleveld and Brownsword (2001, Chapter 5).
} 
values, rules, or principles he may permit to guide his conduct, he must accept everything necessary to avoid contradicting that he is an agent and take no account of considerations not so compelled unless these are necessary truths in se.

The operative concept of agency is not empirical. The key question is, "What may an agent do?' So, Albert must be able to ask the question, 'What is it rational or permissible for me to do?' and have capacities that make it intelligible to prescribe that he may or ought to do something. As such, Albert must be able to pursue purposes voluntarily and perceive the need to do something in order to achieve his chosen purposes. So, as an agent, Albert may be depicted as claiming, 'I do X voluntarily for my chosen purpose E'.

It is clear that Albert necessarily attaches a positive value to $E$ sufficient to motivate him to do $X$, otherwise he would not be doing $X$ voluntarily for $E$. This is a very thin notion of 'valuing'. It ascribes to Albert no more than a positive attitude towards $E$ sufficient to motivate him to do $X$ that he does not feel compelled to have. ${ }^{6}$ It is possible for Albert to consider that he ought not to do $E$ on the basis of values he espouses contingently, yet value $E$ in this sense.

If Albert thinks that doing $X$ is necessary for him to achieve $E$ then he ought to value $X$ as much as he values $E$, or give up pursuit of $E$. This expresses the principle of instrumental reason. If Albert does not accept this principle, then it is clear that he does not understand what it is to be an agent. The point of acting is to achieve one's purposes. This point is utterly negated if the agent does not appreciate the need to do what is necessary to achieve the agent's purposes. So, on pain of contradicting that he is an agent (i.e., on pain of failing to act consistently with a proper understanding of what it is to be an agent), Albert must recognise that he ought to be motivated to pursue whatever he views as necessary to achieve his purposes or abandon these purposes. $^{7}$

It follows that if Albert thinks that something is generically needed for him to pursue or achieve his purposes (and there can be degrees of such need), ${ }^{8}$ then it is dialectically necessary for him to accept that, in order to pursue or achieve his purposes (whatever these might be), he ought to be motivated to do whatever is necessary for him to retain having these conditions unless he is willing to compromise generically his ability to act to at least some degree. In other words, it is dialectically necessary for Albert to accept, 'I categorically instrumentally ought (for my purposes) to defend my possession of the generic conditions of agency'.

No assumption may be made on this basis that Albert necessarily views or should view his agency as an end in itself. There is no implication that Albert contradicts

\footnotetext{
${ }^{6}$ There is no presumption that Albert has free-will. Even if determinism is true, voluntary behaviour can still be distinguished from non-voluntary and involuntary behaviour. Albert's behaviour is voluntary if he feels like he is the self-cause of his behaviour regardless of what is, or what he believes to be, truly the case.

${ }^{7}$ According to Kant, this principle, expressed as 'He who wills the end necessarily wills the means', is analytic $(1785,4: 417)$. This is better expressed as 'He who wills the end necessarily ought to will the means, or give up the end'. This principle is prescriptive, not a (false) description of how agents necessarily behave. In my opinion, while it is analytic that the principle is dialectically necessary, it is not analytic in itself. This, however, makes no difference in practice.

${ }^{8}$ See Gewirth's ‘Criterion of Degrees of Necessity for Action' below.
} 
that he is an agent if he considers it permissible for him not to defend his agency, or even if he does things that damage or risk damage to his agency (even to the extent of ending it completely), provided that he understands and accepts the generic negative implications of this for his ability to act. Therefore, it is only dialectically necessary for Albert to accept, 'Unless I am willing to accept generic damage to my capacity to act, I categorically ought to defend my possession of the generic conditions of agency'.

\section{Stage II}

Any lack of the generic conditions of agency will generically hinder Albert in defending his possession of these conditions. Because reason may require Albert to do something only to the extent that he can do it, it follows that it is dialectically necessary for Albert to hold, 'Unless I am willing to accept generic damage to my capacity to act, I categorically ought to have the generic conditions of agency whenever this is possible'.

However, if other agents (e.g., Brenda) interfere with Albert's possession of the generic conditions of agency or do not assist him to retain them when he cannot do so by his unaided efforts, Albert's capacity to defend these conditions will be compromised generically.

It follows that it is dialectically necessary for Albert to hold, 'Unless I am willing to accept generic damage to my capacity to act, Brenda categorically ought not to deprive me of the generic conditions of agency and categorically ought (when she is able) to assist me to retain these conditions (when I am unable to do so by my own unaided efforts)'.

In other words, it is dialectically necessary for Albert to hold, 'Brenda categorically ought not to deprive me of the generic conditions of agency against my will and categorically ought (when she is able) to assist me to retain these conditions (when I cannot do so by my own unaided efforts) unless I do not so will' ${ }^{9}$

In this sense, it is dialectically necessary for Albert to hold, 'I have negative and positive rights to the generic conditions of agency'.

\section{Stage III}

It follows logically (not from the proposition that Albert considers that he has the generic rights, but from the proposition that it is dialectically necessary for him to consider that he has the generic rights) that it is dialectically necessary for Albert to hold, 'It is merely because I am an agent that I have the generic rights'.

This is because, if Albert denies the conclusion, he asserts by implication that he has the generic rights only because he has some feature agents do not necessarily have (like being male; being called Albert; being of a certain age, height, disposition,

\footnotetext{
${ }^{9}$ Because Albert might not be in a position to ask for assistance when he needs and wants it, Albert must hold that Brenda is released from her duty to assist him only if he objects to her assistance, not merely when he fails to request assistance. However, if Albert is in a position to ask for assistance Albert must hold that Brenda must ask him whether he desires assistance rather than assume that he does.
} 
political party, nationality, creed, hair or eye colour, etc.). Albert implies that, even though he would still be an agent, if he did not have such a feature he would not have the generic rights. However, per stage II, in absolutely no circumstances may Albert deny that he has the generic rights without contradicting that he is an agent. Hence, it is dialectically necessary for Albert to deny that he needs any feature only contingently connected to his agency for him to have the generic rights. Ergo, it is dialectically necessary for Albert to consider that it is merely because he is an agent that he has the generic rights. ${ }^{10}$

It follows that it is dialectically necessary for Albert to accept, 'Brenda (who represents any other agent) also has the generic rights'. If Albert denies this he does not understand what it means to say that it is merely because he is an agent that he has the generic rights.

It is therefore dialectically necessary for Albert to accept the PGC. Since all agents must accept parallel reasoning, it follows that the PGC is dialectically necessary for all agents.

\section{Part Two: An Alternative Argument}

Sceptics generally object to stage II or stage III. For various reasons, they are convinced that either stage II or stage III (or both) cannot follow purely logically from stage I. They maintain that Albert cannot be required to grant Brenda the generic rights unless he is committed to treating Brenda's need for the generic conditions of agency as though they were his own, which will only necessarily be the case if he necessarily values Brenda's purposes like his own (which is not the case). I disagree, but I am here interested specifically in the implications of stage I for the interpretation of human rights, not with the validity of Gewirth's argument as a whole.

Suppose, then, that stage I is valid, and that Albert is, purely as a matter of contingent fact, committed to treating Brenda with the same concern and respect as he treats himself (i.e., wholly impartially) in that he considers that Brenda's need for the generic conditions of agency must be treated as though her need were his own. In other words, let us assume that Albert regards Brenda's need for the generic conditions of agency as having the same relevance as Albert's need for these conditions in determining what Albert may do.

It follows that, on pain of contradicting this impartiality (or denying that he is an agent), Albert must hold, 'Unless Brenda is willing to accept generic damage to her capacity to act, I (Albert) categorically ought to act in Brenda's generic agency interests' $\equiv$ 'I categorically ought to act in Brenda's generic agency interests, in accordance with Brenda's will' $\equiv$ 'Brenda has the generic rights'.

Since Brenda represents any agent other than Albert, Albert must, on pain of denying that all agents categorically ought to be treated wholly impartially (or that he is an agent), accept 'All agents (i.e., Albert plus Brenda) have the generic rights' $\equiv$ 'all permissible actions must be consistent with the PGC'.

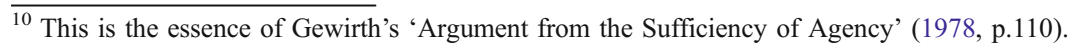


Now, according to the Preamble of the UDHR, all 'members of the human family', all 'human beings', and all 'human persons' are equal in inherent dignity and inalienable rights, and Article 1 UDHR proclaims, 'All human beings are born free and equal in dignity and rights. They are endowed with reason and conscience and should act towards one another in a spirit of brotherhood', and Article 2 UDHR states, 'Everyone is entitled to all the rights and freedoms... [of the UDHR]... without distinction of any kind'. If all human beings are equal in dignity and rights then whether or not the UDHR intends what the second sentence of Article 1 implies (that all human beings are agents), ${ }^{11}$ it certainly entails that all human agents categorically ought to be treated as equal in dignity and rights.

Now, it should be clear that if these provisions constitute or entail commitment to the complete impartiality we have attributed to Albert, then it follows that the UDHR is committed to the PGC by these provisions on pain of denying that the UDHR can have any coherent application to or by agents. However, the PGC requires impartiality as between agents towards the generic conditions of agency, whereas the impartiality expressed by the UDHR is as between humans (including human agents) towards the rights of the UDHR. So, to show that the UDHR is committed to the PGC it must be shown either that to declare that there are any human rights implies declaring that human agents have human rights to the generic conditions of agency or that it is dialectically necessary for Albert to consider that he has the generic rights (which requires it to be shown that Stage II of the dialectically necessary argument is valid).

It should, therefore, be noted that simple appreciation of the concept of a generic condition of agency requires those who accept the UDHR to hold that human agents have human rights to the generic conditions of agency. This is because it is insincere to declare that Albert has a right to do something yet deny Albert a right to possess the means necessary for him to exercise that right. Because the generic conditions of agency are needed to be able to exercise any right to act, no matter what human rights to act the UDHR might declare, human rights to the generic conditions of agency are implied. Of course, without more, it does not follow that the rights must be the generic rights as understood in the dialectically necessary argument. This is because the generic rights of the PGC are rights under the will conception, meaning that if Albert has the rights he can release Brenda from her correlative duties to act in accordance with Albert's generic agency interests. However, the rights to the generic conditions of agency implied by the UDHR must be assigned this character if they are to be compatible with the dialectical necessity of the conclusion of stage I. Since this is so, the UDHR's axiomatic recognition of equal dignity and inalienable rights also entails acceptance of the rights granted by the PGC per se.

In any event, that the coupling of stage I with a commitment to complete impartiality requires Albert to grant the generic rights to Brenda itself entails that stage II of the dialectically necessary argument is valid. This has not hitherto been appreciated either by Gewirthians (including myself) or by Gewirth's critics, and surely constitutes a refutation of all scepticism about stage II. If (as is the case) Albert must grant the generic rights to Brenda simply in consequence of having the same attitude towards her need for the generic conditions of agency as he must have

$\overline{{ }^{11} \mathrm{I} \text { will return to this issue below. }}$ 
towards his own need for these conditions (and this is all that the complete impartiality assumption requires), then the attitude Albert must have towards his need for the generic conditions of agency must be equivalent in meaning to or entail that he has rights to these conditions. This semantic implication does not rely on assuming that Albert is actually committed to the complete impartiality assumption. It is a direct implication of the fact that if Albert were to have the same normative attitude towards Brenda's need for the generic conditions of agency as he must have towards his own need he would be required to grant Brenda the generic rights. The point is this. It is true that we are assuming that it is only because he makes the impartiality assumption that Albert is normatively required to have the same attitude towards that fact that Brenda categorically ought to defend Brenda's possession of the generic conditions of agency, unless this is against Brenda's will, as Albert is required to have towards the fact that Albert categorically ought to defend Albert's possession of the generic conditions of agency, unless this is against Albert's will. But it is only because the impartiality assumption requires this attitudinal equivalence that Albert's normative attitude must be that Brenda has the generic rights. It follows that the meaning of Albert's normative attitude to the fact that he categorically ought to defend his possession of the generic conditions of agency must be that he has the generic rights. ${ }^{12}$

If we, now, couple the idea that all humans are equal in inalienable rights with it being dialectically necessary for Albert to consider that he has the generic rights (which Albert must, therefore hold to be inalienable), it follows that Albert must consider that Brenda equally has the generic rights.

It follows, on pain of denying that all human beings are equal in dignity and inalienable rights, that it is dialectically necessary for those who accept and implement the UDHR to consider that all permissible action must be consistent with the requirements of the PGC. It follows that all agents (including judges and legislators) purporting to interpret the instruments of the international legal system of human rights must likewise do so in accordance with the PGC. ${ }^{13}$ In this sense, the validity of stage I of the dialectically necessary argument entails that the PGC is the supreme principle of human rights.

\section{Part Three: Interpretive Effect and Limitations of the Alternative Argument}

To appreciate what this alternative argument entails, it is necessary to appreciate the interpretive consequences of the dialectically necessary argument if it is valid in its entirety.

\footnotetext{
12 If stage I is sound, this argument implies that the only possible problem with the dialectically necessary argument lies with stage III. To my knowledge, the only critics who are sceptical about stage III who have yet to take Gewirth's actual argument for stage III seriously are Scheuermann (1987) and Chitty (2008). For replies, see Beyleveld (1991), pp.288-300, and Beyleveld and Bos (2009) respectively.

${ }^{13}$ Although the UDHR is not itself a legally binding instrument, legally binding instruments such as the International Covenant on Civil and political Rights and the European Convention on Human Rights make it quite clear in their Preambles that they exist to give effect (at least in part) to the rights of the UDHR. They can only do so on the understanding that it is the rights proclaimed by the UDHR as conceived by the UDHR that they are giving effect to.
} 
Interpretive and Justificatory Effect of the Dialectically Necessary Argument

The dialectically necessary argument renders it dialectically necessary for agents to grant rights to the generic conditions of agency: (1) to all agents (and without more only to agents), (2) under the will conception; (3) that are both positive and negative, (4) that are inalienable, and (5) it requires conflicts between rights to be adjudicated using the 'criterion of degrees of necessity for action' (Gewirth 1978, pp. 343-344).

\section{Rights of Agents and Human Rights}

The dialectically necessary argument grants the generic rights per se only to agents because they are rights under the will conception. Only if Albert is an agent is he able to release those who have duties correlative to his rights from these duties by the exercise of his will. It is unintelligible to grant a non-agent a right under the will conception. Therefore, Gewirth (1978, pp. 119-125, pp. 140-145) is mistaken when he holds that agents must grant the generic rights per se to partial and potential agents ('marginal agents') in proportion to how closely they approach being agents (Beyleveld and Pattinson 2000). Agents must be granted all the generic rights. Nonagents cannot be granted any generic rights per se at all.

However, it does not follow that it is not dialectically necessary for agents to acknowledge duties to protect interests of human beings (biologically identified) who do not display the capacities of agency (human 'apparent non-agents'; and indeed non-human apparent non-agents). Such duties can arise in two ways.

First, they can arise vicariously from the relationship between the apparent non-agent and an agent being such that to harm or permit harm avoidably to the apparent non-agent is to threaten or violate the generic rights of the agent. Here the duty owed by an agent in relation to an apparent non-agent is not a duty owed directly to the apparent non-agent, but a duty in relation to the apparent non-agent owed directly to some other agent (Beyleveld 2000, pp. 62-64). It is important to appreciate that 'rights' required to be recognised by the PGC do not have to be generic rights per se. They merely have to be justified by the need to protect generic rights per se. Nevertheless, the difficulty with justifying 'human rights' on this basis is that vicariously justified rights depend on contingent attitudes of agents or relationships between agents and human apparent non-agents and not on the essence of being human.

Second, such duties arise directly from the need to exercise precaution to guard against the possibility of harming what might possibly be an agent. Because agency involves capacities like self-awareness, only Albert can know directly that Albert is an agent; he cannot know directly that Brenda is an agent. All that Albert can know directly is that Brenda behaves as though she is an agent. This proposition does not involve any commitment to the inherent privacy of mental states beyond the incontrovertible fact that agents can only experience their own pains and pleasures and their own feelings. It does not involve the idea that Albert cannot make inferences about the mental states of others and happen to be right. It merely involves that, unless Albert makes various purely speculative and wholly unverifiable metaphysical assumptions, or arbitrarily defines agency in terms of agency-like behaviour, he has no basis to infer from Brenda's behaviour that Brenda is an agent any more (or less) than he has a basis to infer that an android that behaves 
like an agent is an agent. ${ }^{14}$ This cognitive deficiency is part of the very essence of being human. Now, suppose that Albert can treat Brenda like an agent because she behaves like one, but he supposes that Brenda is not an agent, acts accordingly, and (though he cannot know this incontrovertibly) is wrong. He will have done what the PGC absolutely prohibits him to do, which is not to respect the generic rights of an agent when he was able to do so. On the other hand, if Albert supposes that Brenda is an agent, acts accordingly, and is wrong, he will not have done anything that the PGC absolutely prohibits. Therefore, it is dialectically necessary for Albert to treat apparent agents (those whom he can treat as agents) as agents and grant them the generic rights. It follows that, under the dialectically necessary requirement to comply with the PGC, it is dialectically necessary to treat agency-like behaviour as evidence of agency.

It is debatable whether or not there is sufficient behavioural evidence to classify a chimpanzee or a dolphin as an apparent agent. We should probably class these creatures as 'uncertain apparent non-agents (or agents)'. As for cats or dogs, horses or pigs, there is probably sufficient evidence to conclude that they are not apparent agents, and we should class them as 'probable apparent non-agents'. As for previously apparent agents now in a persistent vegetative state, or human foetuses, there is enough evidence to conclude that they are not apparent agents. They are 'certain apparent non-agents'. However, in none of these cases may we conclude that the being is certainly not an agent. There are various speculative possibilities under which any of these beings could be agents. However, insofar as they lack the capacity to behave like agents, it is not possible to treat them as agents. Therefore, because 'ought' implies 'can', precaution under the dialectical necessity of the PGC does not require any apparent non-agents (which includes rocks and tables, which could also be agents) to be treated as agents (Beyleveld and Pattinson 2010). Nevertheless, the dialectical necessity of the PGC requires agents to guard against mistakenly treating them as non-agents to the extent that it is possible and meaningful for agents to do so. Precisely what this means is beyond the scope of this article. For present purposes, it will suffice to say that it is dialectically necessary for agents, as far as this is possible and meaningful, not to act towards apparent nonagents in ways that would constitute violating their generic rights should they (unknowably) happen to be agents. Hence, for example, Albert has at least a prima facie duty not to cause debilitating pain to a dog, because to do this to an agent against the agent's will would violate a generic right of the agent. In general, Albert has duties to apparent non-agents in proportion to the degree that they approach being apparent agents, the degree of approach being a function of the degree to which the characteristics and capacities of the apparent non-agent can be related to interests that correspond to the generic interests of agents. Difficult questions arise in relation to the strength (normative force) of these duties when they come into conflict with the rights of (apparent) agents. However, the generic rights of agents themselves vary in strength. ${ }^{15}$ In principle, these conflicts are to be adjudicated by weighing the PGC-guided precautionary probability that an apparent agent is an agent $(=1)$ multiplied by the strength of the generic right in question against the precautionary probability that an apparent non-agent is an agent $(=>0<1)$ multiplied

\footnotetext{
14 The issues are graphically illustrated by films like Blade Runner and I Robot.

${ }^{15}$ See further below, in relation to the criterion of degrees of necessity for action.
} 
by the strength of the conflicting generic right-corresponding interest of the apparent non-agent. While it is difficult to see how this can be operationalised in a wholly objective way, the problems are of kinds that confront all cost-benefit and risk analyses (Beyleveld and Brownsword 2001, pp. 119-134, pp. 255-258). ${ }^{16}$

For simplicity, I will refer to the generic rights of agents as 'will-rights' and to dialectically necessary duties agents owe to apparent non-agents as correlative to 'interest-rights'. It should be clear that if we distinguish between these two categories, then it is dialectically necessary for agents to consider that being a living human being is sufficient to confer at least some rights to interests corresponding to the generic conditions.

However, if human rights are justified in this way, this conflicts with the UDHR's claim that all human beings possess all human rights equally. At once it must be said that if the PGC is dialectically necessary and comes into conflict with the Declaration on any point, then so much the worse for the UDHR.

At the same time, it is not wholly clear what the conflict is. For example, while Article 1 UDHR proclaims that all human beings are born free and equal in dignity and rights, it also says that all human beings are endowed with reason and conscience and should act fraternally towards one another. As I have already said, taken literally, this implies that to be a human being is to be an agent, and that human non-agents do not qualify as human beings for the purposes of the UDHR. If so, the conflict is not that the PGC grants rights directly only to agents whereas the UDHR grants them to all human beings, but that the PGC grants rights to all human beings (biologically defined; full will-rights to human apparent agents and some interest rights to human apparent non-agents) whereas the UDHR grants rights only to (apparent) agents.

However, account must be taken of, e.g., the United Nations Declaration on the Rights of Mentally Retarded Persons 1971, according to which mentally retarded persons have 'to the maximum degree of feasibility, the same rights as other human beings'.

This idea is consistent with the position that the PGC justifies. However, it can be squared with Article 1 UDHR only by revising or radically interpreting this Article to state something like, 'All human beings viewed in terms of the capacities of the human species are born free and equal in dignity and rights. The human species is endowed with reason and conscience, and all human beings so endowed should act towards one another in a spirit of brotherhood'.

Unless the UDHR really does grant human rights only to human agents, something like this is necessary in any event, because if Article 1 refers to 'human beings' as biologically defined both of its statements are empirically false.

The PGC scheme is also compatible with Article 1 of UNESCO's Universal Declaration on the Human Genome and Human Rights 1997, especially when this is read with the Preamble to the Council of Europe's Convention on Human Rights and Biomedicine 1998. The UNESCO Declaration states that the human genome 'underlies... the recognition of' the inherent dignity of all members of the human

\footnotetext{
$\overline{16}$ The precautionary reasoning outlined here only applies in situations where, for one or other reason, it is not possible to make any estimate of the probability of generic harm beyond the fact that it is not zero. It does not apply, e.g., to calculations of the risk to life involved in crossing the road, or driving a car, where probability estimates, however, rough, can be made and standard cost-benefit analysis is applicable (see further, Beyleveld and Brownsword 2009).
} 
family, while the Biomedicine Convention holds that 'the human being' must be respected 'both as an individual and as a member of the human species'. 17

This, however, raises another problem, which is that Article 2 UDHR, according to which all human beings have all the UDHR's rights and freedoms without distinction of any kind, does not square with the PGC scheme (or for that matter the UN's 1971 Declaration) either. This can only be remedied by reading Article 2 UDHR as saying that all human beings have all the UDHR's rights and freedoms without distinction of any kind to the extent that they are capable of exercising them.

In fact, this reading is necessary even without trying to square the UDHR with the PGC. This is because the UDHR and other instruments in the international legal system of human rights specify some rights that only agents are capable of exercising. As far as the European Convention on Human Rights is concerned, the Article 9 right to freedom of thought, religion and conscience; the Article 10 right to freedom of expression; and the Article 12 right to marry come immediately to mind. Indeed, there is a further problem with Article 12. The right is granted only to those of an age much higher than that at which most human beings achieve apparent agency. Therefore, the Article 12 right might not be properly classified as a human right. It is beyond the scope of this paper to determine whether or not this is so. However, for there to be any possibility that the Article 12 right is a human right it is necessary to think of human rights as a system of rights belonging to human beings simply by virtue of being human rather than as a set of rights that individually are held equally and without distinction of any kind by all human beings.

\section{Rights under the Will Conception}

That the generic rights are rights under the will conception entails that human agents do not have duties to protect or not harm their own generic interests if they do not wish to do so, unless allowing them to harm or not protect themselves endangers at least equally important generic rights or interests of others. It also means that if a human agent gives free and informed consent to non-protection of his or her generic agency interests then this does not constitute interference with the right corresponding to that interest. In short, agents owe no perfect duties to themselves to protect their generic agency interests under the PGC. ${ }^{18}$ Furthermore, it entails that not to permit an informed agent to engage freely in activities that are harmful to the agent's generic interests is contrary to the specific dignity of agents, which must reside, at least in part, in their capacity to direct their actions through their own choice. This is because, according to the Preamble of the International Covenant on

\footnotetext{
$\overline{17}$ The compatibility is clearest if 'an individual' is interpreted as 'a human agent' and 'a member of the human species' is interpreted as 'a being having the human genome'.

Some degrees of mental retardation are so severe that the human being in question can only be classified as a certain apparent non-agent (more probably an apparent non-agent than a cat, let alone a chimpanzee). It follows that the PGC requires non-human animals also to be granted at least interest-rights to the maximum degree of feasibility. This does not, however, mean that the PGC requires animals to be granted rights, e.g., under the European Convention on Human Rights. The question is one of jurisdiction, the European Convention being a convention on human rights. The PGC does not require all the rights it recognises, even though they might be equivalent, to be dealt with under the same legal instrument.
}

${ }^{18}$ Gewirth (1978, pp.333-338) thinks otherwise; but I think he is wrong (see Beyleveld and Brownsword 2001, pp.106-108). 
Civil and Political Rights, the rights of the UDHR 'derive from the inherent dignity of the human person'. The dignity of human agents must reside in their capacities for action if the PGC is dialectically necessary, because Gewirth's Argument from the Sufficiency of Agency (crucial to Stage III of the dialectically necessary argument, as we have seen) shows that it is dialectically necessary for agents to hold that it is by virtue of being agents that they have the generic rights. ${ }^{19}$

This fits a persistent line of thinking of the European Court on Human Rights (the 'Strasbourg Court'). For example, in $Z v$ Finland $^{20}$ and M.S. $v$ Sweden, ${ }^{21}$ the Strasbourg Court held that Article 8(1) of the European Convention on Human Rights $^{22}$ is engaged if the personal medical data of an individual is used without the explicit consent of that individual. Interference with Article 8(1) occurs unless such use is justified in terms of Article 8(2). ${ }^{23}$

Then, in Pretty $v U K,{ }^{24}$ the Strasbourg Court held that Article 8(1) was engaged by Section 2(1) of the UK's Suicide Act 1961 making it a criminal offence to assist a suicide, thereby preventing Dianne Pretty who was dying with motor neurone disease from being assisted by her husband to commit suicide. Dianne Pretty had also claimed that the UK was in violation of Article 2 of the European Convention, which grants a right to life, because the right to life must include how one chooses to live and this includes how one chooses to die. The Strasbourg Court held that the right to life does not include a right to commit suicide, ${ }^{25}$ which is correct under the PGC because death is not a generic condition of agency. However, a right to commit suicide does exist as an expression of a right to choose how one lives (as a function of a right to autonomy, i.e., a right to choose how to live one's life, to which the Strasbourg Court has given full expression under Article 8(1) of the European Convention on Human Rights). ${ }^{26}$

However, the UK House of Lords, while holding wrongly that Article 8(1) was not engaged, had opined that if it is engaged then there are sufficient reasons under

\footnotetext{
$\overline{19}$ Kant's Formula of Humanity for the moral law (1785, 4:429) requires Albert to treat all agents as ends in themselves and not merely as means to ends (and that includes Albert). The PGC requires Albert to treat Brenda as an end in herself and not merely as a means to his ends, but does not prohibit him from treating himself as a means to his own ends, because it interprets treating an agent as an end in itself as respecting an agent's generic agency interests in accordance with that agent's free and informed consent.

${ }^{20}$ [1997] ECHR 10 (25 February 1997).

21 (1997) 28 EHRR 313.

22 According to which 'Everyone has the right to respect for his private and family life, his home and his correspondence'.

${ }^{23} Z v$ Finland at paras 96-97. M.S. $v$ Sweden at para 34. According to Article 8(2), a public authority may not interfere with the right of Article 8(1) except in accordance with the law and if necessary in a democratic society

in the interests of national security, public safety or the economic well-being of the country, for the prevention of disorder or crime, for the protection of health or morals, or for the protection of the rights and freedoms of others

The PGC only permits generic rights to be overridden by other (at least as important) generic rights. So exceptions to a human right, even if not specified as for the rights of others, must protect the human rights of others or cannot be considered legitimate potential overriding considerations. In principle, the exceptions of Article 8(2) can all qualify under this test in particular circumstances.

24 (2002) 35 EHRR 1, at paras 61-67 and 86.

25 ibid., paragraphs 39 and 42 .

${ }^{26}$ Indeed, according to Loucaides (1990, p.196), 'for all practical purposes, the right to privacy has become a functional equivalent of a right of personality'.
} 
Article 8(2) of the European Convention on Human Rights not to permit Dianne Pretty to exercise this right. ${ }^{27}$ The Strasbourg Court considered that this was an acceptable judgement under the doctrine of the margin of appreciation that it allows to member states to interpret provisions of the Convention. ${ }^{28}$ While it is arguable that this was a poor opinion in fact, the form of reasoning is entirely consistent with the will conception of rights.

\section{Positive as Well as Negative Rights}

That the generic rights are positive as well as negative follows from the fact that the dialectically necessary argument is driven by an agent's categorical instrumental need for the generic conditions of agency. To ensure that this need is satisfied it is as necessary for Albert to be assisted in defending his generic conditions of agency when he cannot do so by his own unaided efforts as it is necessary for him not to be deprived of these conditions by others. Hence, the dialectical necessity of the PGC not only requires agents (negatively) not to interfere with the generic conditions of agency of others but (positively) requires them to assist needy agents to secure these conditions when they are able to do so. This requirement is, however, subject to the proviso that positive action to protect Albert's generic conditions of agency cannot be required of Brenda (assuming it falls to her to provide assistance) if her assistance conflicts with comparable or more important generic conditions of agency of Brenda. For reasons beyond the scope of this article, the discharge of many positive duties falls primarily on states and institutions, as representatives of collectivities of individuals, rather than directly upon individuals (Gewirth 1996. p.59).

As we have seen, agents have a PGC supported right to be assisted to commit suicide under a generic right to freedom of action (autonomy). However, because the exercise of this right is subject to it not conflicting with at least equally important rights of others, agents do not have a duty to assist those wishing to be assisted in

\footnotetext{
${ }^{27} R$ on the Application of Mrs Dianne Pretty (Appellant) v Director of Public Prosecutions (Respondent) and Secretary of State for the Home Department (Interested Party) [2001] UKHL 61, e.g. Lord Bingham at paras 26-30; and Pretty $v$ UK (2002) 35 EHRR 1, at paragraphs 61-67 and 87.

28 ibid., at paragraphs $68-78$. The PGC may be applied directly or indirectly. Direct applications involve judging whether or not, and to what degree, actions are compatible with the preservation of the generic conditions of agency in accordance with an agent's will. Such judgments can be complex and controversial, the relative importance of generic conditions of agency can be difficult to assess, some matters that the PGC treats as intrinsically optional (like driving on the left or right hand side of the road) nevertheless need an authoritative decision, and so on. The PGC deals with this indirectly by, through its direct application, allowing decisions to made by various procedures (depending on the nature of the issue), such as a majority vote, tossing a coin, the decision of a judge or an expert panel, etc. These it treats as binding as long as the procedures prescribed by its direct application are adhered to. The indirect applications will also permit states to extend rights and duties by consent that are not required directly by the PGC. All of this is beyond the scope of this paper (see Beyleveld and Brownsword 2007, Chapter 10). The doctrine of the Strasbourg Court that the meaning and scope of a right is to be determined by the Court, but member states have a margin of appreciation when deciding when the facts permit an exception to the right (should there be any permitted; e.g., S. and Marper $v$ UK (2009) 48 EHRR 50, at paragraphs 101-102) is in line with the indirect applications of the PGC. Member states of the Council of Europe will want an harmonised interpretation of what the rights of the European Convention on Human Rights actually are; but domestic courts are in a better position than the Strasbourg Court to judge what conflicts of rights are presented in a case due to being in a better position to understand the factual context in which the actions presented by the case take place.
} 
committing suicide if they do not wish to do so under their own right to freedom of action. In practice, if not in concept, this entails that there is no positive right to such assistance in this case. Any effective positive right to be assisted to commit suicide needs to be rooted in a substantive right, such as the right not to be subjected to inhuman or degrading treatment or torture, which is recognised by Article 3 of the European Convention on Human Rights. Dianne Pretty had also claimed a right to be assisted to commit suicide under Article 3, on the grounds that she faced the prospect of suffocating to death as her disease progressed, and that to allow this against her will would constitute inhuman and degrading treatment. In PGC terms, I consider that the Strasbourg Court was wrong to deny this claim, which it did by treating the Article 3 right as exclusively negative in this case. ${ }^{29}$

\section{Inalienability}

The dialectical necessity of the generic rights renders them inalienable, because they must be granted to agents simply by virtue of being agents. That they are inalienable does not mean that it is impossible for them not to be recognised. It means that it is categorically impermissible for them not to be recognised. To say that a right exists is not to say that the duties that are correlative to the interest that the right protects are recognised. It is to say that these duties ought to be recognised whether or not they are recognised.

This is compatible with the rights being rights under the will conception. While it is often said that the will conception permits agents to waive (give up) any rights they have, this is loose talk. The generic rights of agents are by definition rights for agents to have their generic agency interests secured in accordance with their will. If Albert permits Brenda to interfere with his generic conditions of agency, he is not waiving his right to non-interference against his will. The interference is in accordance with his will. The interference that he permits is not interference with the right itself but merely with the interest that the right protects. Albert is declining to defend the interest protected by the right, not waiving the right, and the permissibility of this is built into the kind of (inalienable) right that it is.

\section{The Criterion of Degrees of Necessity for Action}

Generic conditions of agency do not necessarily have an all or nothing effect on action or successful action. If they did there could be very few generic needs. In fact, something is a generic condition if its absence to some degree diminishes or, if its deprivation continues, will tend to diminish an agent's ability to act or to act successfully regardless of the agent's purposes. For this reason, the generic conditions of agency are organised into a hierarchy of importance. Basic generic needs outrank non-subtractive generic needs, which outrank additive generic needs. Within these categories there is also a hierarchy (Gewirth 1978, pp. 62-63). Reference to this hierarchical ordering is use of what Gewirth calls the 'Criterion of Degrees of Necessity for Action'. Its justification is merely an application of the Principle of Instrumental Reason, ${ }^{30}$ and the Criterion of Degrees of Necessity for

\footnotetext{
$\overline{29}$ (2002) 35 EHRR 1, at para 56.

${ }^{30}$ See above. This principle is analytically connected to the principle that 'ought' implies 'can'.
} 
Action is dialectically necessary for the same reason that the Principle of Instrumental Reason is dialectically necessary.

The Criterion of Degrees of Necessity for Action is central to the way in which the PGC views conflicts between rights. Since the rights the PGC grants are rights to the generic conditions of agency, the rights themselves are to be ranked according to the Criterion of Degrees of Necessity for Action (Gewirth 1978, pp. 343-344). No discrimination can be made between the strength of the generic interest protected in an interest right and in a will-right. However, as I have already mentioned, the weight given to the will-right of an apparent agent must be greater than the interest right of an apparent non-agent when the same interest defines the right. Thus, the right to life of a mother will outrank the right to life of her unborn baby (if the two are in conflict), because the precautionary probability of the mother being an agent is 1 , whereas that of the unborn baby is $<1$. Difficulties arise when trying to weigh the rights of an apparent agent against an apparent non-agent when the same generic interest is not in conflict. Amongst other things, this is because this weighing requires a specific value $>0<1$ to be assigned to the precautionary probability of the apparent non-agent being an agent, for which there is no obvious dialectically necessary answer (Beyleveld and Brownsword 2001, pp. 255-258).

\section{Limitations of the Alternative Argument}

If the dialectically necessary argument is sound, it provides a dialectically necessary justification directly for the idea that all agents (including human agents) are equal in dignity rights, without discrimination. This renders the individual generic rights inalienable rights possessed by agents simply because they are agents. This, in turn, makes their existence (as against their recognition or enforcement) wholly independent of their recognition by agents or states. Under the consequent dialectical necessity of precaution, it not only renders it dialectically necessary to grant these same rights with the same force to all apparent agents, but renders it dialectically necessary to grant applicable interest rights to apparent non-agents (including human apparent nonagents) to the maximum degree that it is feasible to do so, which are again inalienable. Consequently it is able to refute the allegation that the very idea of human rights is ethnocentric, the mere product of a contingent, historically transient culture.

My alternative argument does not render the PGC dialectically necessary. This is because it conjoins the premise that it is dialectically necessary for agents to accept that they categorically instrumentally ought to defend their own possession of the generic conditions with the dialectically contingent premise that all human beings categorically ought to be treated as equal in dignity and human rights. Since an argumentative chain is only as strong as its weakest link, this argument does not show that it categorically must be accepted that human rights (whether individually or as a system) are held equally and inalienably, and exist independently of recognition by agents/states. ${ }^{31}$ Such a

\footnotetext{
${ }^{31}$ For some other dialectically contingent arguments for the PGC, see Beyleveld (1996) and Beyleveld and Brownsword (2001), pp.77-86, pp.91-96. The present argument can be viewed as a version of what is there called 'the argument from categorically binding other-regarding requirements on action', or 'the argument from morality'. It is different from the argument from human rights in Beyleveld (1996) and Beyleveld and Brownsword (2001) in that the latter does not use Stage I, focuses on the European Convention on Human Rights, and relies on contingencies of the jurisprudence of the Strasbourg Court.
} 
demonstration requires either the whole of Gewirth's dialectically necessary argument to be valid (which I think is the case), or, failing that, some other argument that renders it dialectically necessary for agents to treat each other with equal concern and respect. Kant's own argument is an obvious candidate here, though I consider it to be beset with more difficulty than Gewirth's (see Beyleveld and Brownsword 2001, pp. 101105). ${ }^{32}$ The argument of a transcendental discourse theorist like Karl Otto Apel (1980) is another candidate.

Of course, some claim that it is self-evident that agents must be treated with equal concern and respect. ${ }^{33}$ And others (e.g., MacCormick 1984, p. 351) claim that the proper question is not 'Why should I take equal account of the interests of those other than myself?' but 'Why should I not take equal account of the interests of those other than myself?' But self-evidence is too contestable, being disproved by its mere denial. As for the idea that the basic question is why ought I not to act in the interests of others as well as my own, I necessarily value my own freely chosen purposes but do not necessarily value the purposes of others, and this makes my request for a reason to value others' agency interests perfectly in order.

Of course, there can be other reasons for accepting that we should treat others with equal concern and respect. For example, Gauthier (1986) makes a good case for it being generally in our interests to do so, because we are neither omnipotent nor omniscient. The problem is that 'most cases' is not 'necessarily all cases', so this cannot render human rights inalienable.

Nevertheless, while these difficulties remain if the dialectically necessary argument is not valid in its entirety, many persons and cultures are committed to the idea that all human beings are to be treated with equal concern and respect for their agency. The central claim of this paper is that all who entertain such a premise must, if stage I of the dialectically necessary argument is sound, accept the PGC as the supreme principle of morality and indeed of practical reason. This goes for the international legal system of human rights, which must therefore take the PGC to be the supreme principle of human rights. ${ }^{34}$

Open Access This article is distributed under the terms of the Creative Commons Attribution Noncommercial License which permits any noncommercial use, distribution, and reproduction in any medium, provided the original author(s) and source are credited.

\section{References}

Apel KO. (1980) The a priori of the communication community and the foundation of ethics: the problem of a rational foundation of ethics in the scientific age. In Adey G and Frisby D (eds and trans) Towards a transformation of philosophy. Kegan Paul, London, pp. 225-308

\footnotetext{
32 Kant's argument, unlike Gewirth's, rests on the claim that action under the moral law and possession of free-will are reciprocal concepts and the claim that agents must consider that they have free-will or deny that they are agents (1785, 4:446-448).

33 This includes the American Declaration of Independence of 1776.

${ }^{34}$ I find it ironic that many who have raised doubts about Stages II and III have been willing to accept Stage I while themselves advocating positions that rely on (or argue for) impartiality as an axiom of practical reasonableness, without seeing that they cannot consistently do this without accepting the PGC as the supreme principle of practical reasonableness.
} 
Beyleveld D. (1991). The dialectical necessity of morality: an analysis and defense of Alan Gewirth's argument to the principle of generic consistency. Chicago, University of Chicago Press.

Beyleveld D. (1996). Legal theory and dialectically contingent justifications for the principle of generic consistency. Ratio Juris 1:15-41

Beyleveld D. (2000). The moral status of the human embryo and fetus. In Haker H and Beyleveld D (eds). The ethics of genetics in human procreation. Aldershot: Ashgate, pp. 59-85.

Beyleveld D, and Bos G. (2009). The foundational role of the principle of instrumental reason in Gewirth's argument for the principle of generic consistency: a response to Andrew Chitty. King's Law J 20:1-20

Beyleveld D, and Brownsword R. (2001). Human dignity in bioethics and biolaw. Oxford University Press, Oxford

Beyleveld D, and Brownsword R. (2007). Consent in the law. Hart, Oxford.

Beyleveld D, and Brownsword R. (2009). Complex technology, complex calculations: uses and abuses of precautionary reasoning in law. In Paul Sollie and Marcus Duewell et al (eds) Evaluating new technologies: methodological problems for the ethical assessment of technological developments. Springer, Berlin, pp. 175-190.

Beyleveld D, and Pattinson S. (2000). Precautionary reason as a link to moral action. In Boylan M (ed) Medical ethics. Prentice Hall, Upper Saddle River New Jersey, pp. 39-53

Beyleveld D, and Pattinson S. (2002). Horizontal applicability and horizontal effect. Law Q Rev 118:623646

Beyleveld D, and Pattinson S. (2010). Defending moral precaution as a solution to the problem of other minds: a reply to Holm and Coggon. Ratio Juris 23:258-73.

Boylan M (ed). (1999). Gewirth: critical essays on action, rationality, and community. Rowman and Littlefield, Lanham, Maryland.

Chitty A. (2008). Protagonist and subject in Gewirth's argument for human rights. King's Law J 19:1-26.

Gauthier D. (1986). Morals by agreement. Oxford University Press, Oxford.

Gewirth A. (1978). Reason and morality. University of Chicago Press, Chicago.

Gewirth A. (1996). The community of rights. University of Chicago Press, Chicago.

Kant I. (1785). The groundwork for the metaphysics of morals. Gregor M (ed and trans). Cambridge University Press, Cambridge, 1998.

Loucaides LG. (1990). Personality and privacy under the European Convention on Human Rights, British yearbook of international law, LXI, pp. 175-197

MacCormick N. (1984). Gewirth's fallacy. Queen's Law J 9:345-351.

Regis E Jr. (ed). (1984). Gewirth's ethical rationalism; critical essays with a reply by Alan Gewirth. University of Chicago Press, Chicago.

Scheuermann J. (1987). Gewirth's concept of prudential rights. Philos Q 37:291-304.

Spence E. (2006). Ethics within reason: a neo-Gewirthian approach. Lexington books, Lanham, Maryland.

Steigleider K. (1992). Die Begründung des moralischen Sollens. Studien zur Möglichkeit einer normativen Ethik, Attempto, Tübingen. 